Document downloaded from:

http://hdl.handle.net/10251/45298

This paper must be cited as:

Ruiz Martinez, A.; Martin Garcia, N.; Romero Gil, I.; Seco, A.; Ferrer, J. (2012). Microalgae cultivation in wastewater: nutrient removal from anaerobic membrane bioreactor effluent. Bioresource Technology. 126:247-253. doi:10.1016/j.biortech.2012.09.022.

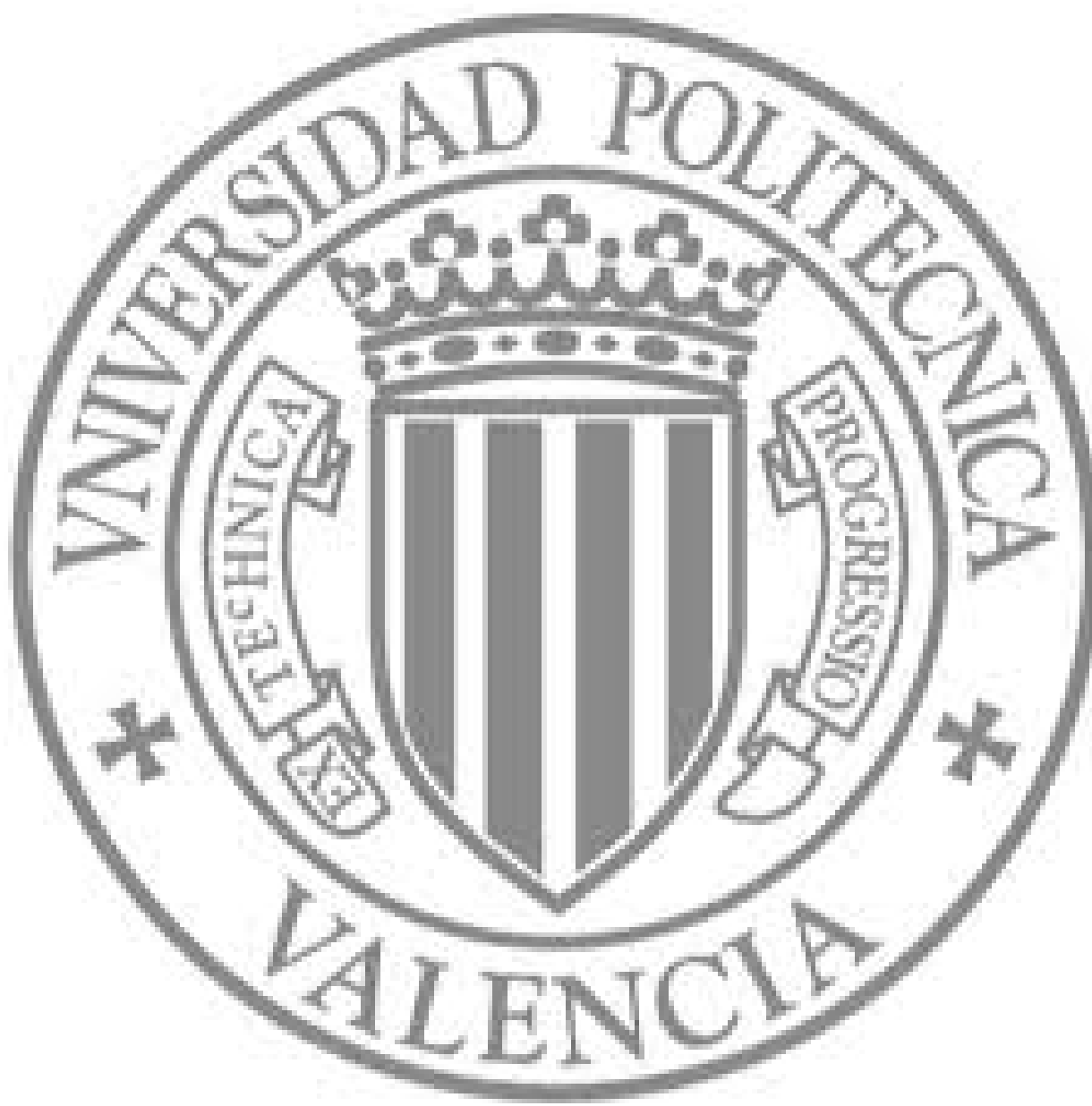

The final publication is available at

http://dx.doi.org/10.1016/j.biortech.2012.09.022

Copyright Elsevier 


\title{
Microalgae cultivation in wastewater: nutrient removal from anaerobic membrane bioreactor effluent
}

\author{
Ruiz-Martinez, A.*,a , Martin Garcia, N. ${ }^{\text {b,1 }}$, Romero, I. ${ }^{\text {a }, ~ S e c o, ~ A . ~}{ }^{\text {, and Ferrer, J. }}{ }^{\text {a }}$
}

${ }^{a}$ Research Institute of Water and Environmental Engineering, IIAMA, Universidad Politécnica de Valencia, Camino de Vera s/n, 46022 Valencia Spain, Valencia, Spain (e-mail: anruima1@upv.es, inrogi@dihma.upv.es, jferrer@hma.upv.es)

bopartament d'Enginyeria Química, Escola Tècnica Superior d’Enginyeria, Universitat de València, Avinguda de la Universitat s/n. 46100 Burjassot, Valencia, Spain (email:

aurora.seco@uv.es, imartin@cetaqua.com)

${ }^{1}$ Present address: CETaqua, Centro Technologico del Agua, Carretera d'Esplugues 75, 08940

Cornellà, Barcelona, Spain

*Corresponding author. Tel. +34 963877000 ext. 76176; Fax +34 963877 618, e-mail address:

anruima1@upv.es

\section{ABSTRACT}

This study investigated the removal of nitrogen and phosphorus from the effluent of a submerged anaerobic membrane bioreactor (SAnMBR) by means of a lab-scale photobioreactor in which algae biomass was cultured in a semi-continuous mode for a period of 42 days. Solids retention time was 2 days and a stable $\mathrm{pH}$ value in the system was maintained by adding $\mathrm{CO}_{2}$. Nitrogen and phosphorus concentrations in the SAnMBR effluent fluctuated according to the operating performance of the bioreactor and the properties of its actual wastewater load. Despite these variations, the anaerobic effluent proved to be a suitable growth medium for microalgae (mean biomass productivity was 234 $\left.\mathrm{mg} \cdot \mathrm{l}^{-1} \cdot \mathrm{d}^{-1}\right)$, achieving a nutrient removal efficiency of $67.2 \%$ for ammonium $\left(\mathrm{NH}_{4}{ }^{+}-\mathrm{N}\right)$ and 
97.8\% for phosphate $\left(\mathrm{PO}_{4}^{-3}-\mathrm{P}\right)$. When conditions were optimum, excellent water quality with very low ammonium and phosphate concentrations was obtained.

\section{Keywords}

Microalgae; nutrient removal; submerged anaerobic membrane bioreactor; wastewater.

\section{INTRODUCTION}

Urban and industrial wastewater must be treated before being discharged into the environment in order to prevent undesirable effects such as pollution and eutrophication. Anaerobic treatments have several advantages over more traditional aerobic systems i.e. they consume less energy and produce less sludge whilst generating biomethane (Ho and Sung, 2010). The combination of anaerobic wastewater treatment with membrane technology gave rise to anaerobic membrane bioreactors, the main advantage of which is the possibility of separating solids retention time (SRT) from hydraulic retention time (HRT), whilst reducing the footprint and achieving high quality effluent in terms of suspended solids. Pilot-scale submerged anaerobic membrane bioreactors (submerged AnMBR or SAnMBR) have been evaluated with promising COD removal rates (Giménez et al. 2011), but discharge into the aquatic environment or water reuse is not possible without further nitrogen and phosphorus removal (Stuckey 2012). There is a clear need for research on post-treatments which allow the extended and full-scale use of AnMBR for domestic wastewater treatment (Smith 2012). Possible traditional treatments such as biological nitrification-denitrification process or enhanced biological phosphorus removal 
are energy-intense. Partial nitritation/nitrification with Anammox bacteria has lately received increasing attention. However, there is still little literature available for low strength wastewaters, and we have not found any author describing AnMBR effluent treatment with Anammox bacteria. The present study is a novel approach to AnMBR effluent post-treatment using microalgae for nutrient removal and biomass generation. The generated biomass allows nutrient recovery and presents an added value for various industrial applications or energy recovery, as it is presented in this section.

The use of microalgae in wastewater treatment was first proposed by Oswald and Gotaas (1957) and has received much attention in recent decades (Olguín et al. 2003a, Rawat et al. 2010). Microalgae are photosynthetic microorganisms which use energy from the sun to grow, consuming inorganic nutrients and $\mathrm{CO}_{2}$. They accumulate organic matter in the form of proteins, lipids, carbohydrates, hydrocarbons and other small molecules and pigments. Microalgal biomass has been studied and used for human and animal nutrition and for producing substances such as fatty acids, $\beta$-carotene, astaxanthin and phycocyanin (Pulz and Gross 2004). In recent decades, however, microalgae have been in the spotlight because of their potential use in producing renewable biofuel, mainly biodiesel, via the transesterification of intracellular accumulated oils. Due to their rapid growth and ability to accumulate oil in concentrations of up to $50 \%$ of their dry weight, together with the possibility of year-round production, microalgae can enable higher oil yield than existing oilseed crops (Schenk et al. 2008). As reported elsewhere, the residual biomass can still be used for energy recovery via thermochemical conversion (gasification, liquefaction, pyrolysis, combustion) or biochemical conversion (anaerobic digestion for biomethane 
production, fermentation for bioethanol production). For a wider review of this topic see Brenan and Owende (2010).

But despite all the technical and biotechnological advances in this field, the start-up and operating costs of algal biofuel production systems are still too high. It was estimated (Chisti 2008) that the costs of algal biodiesel production must be reduced to one tenth if it is to be competitive.

As previously stated, microalgae have been used around the world for wastewater treatment in stabilization ponds or high-rate algal ponds (HRAP). However, these technologies have been used mainly in small communities, partly due to their big spatial footprint. According to Park et al. (2011), the use of HRAPs in wastewater treatment to produce algal biomass has been given little consideration. However, many authors have recently drawn attention again to the potential of combining wastewater nutrient removal and biofuel production, as reviewed by Pittman et al. (2011). With this combination, the nutrients needed for microalgal growth are obtained from wastewater, eliminating the need for clean water and the addition of nutrients, thus reducing production costs. Furthermore, nutrients are not only removed from the wastewater, but can also be captured and returned to the terrestrial environment as agricultural fertilizer. Another advantage of using microalgae to treat wastewater is their photosynthetic $\mathrm{CO}_{2}$ fixation, which contributes to mitigating greenhouse gases. The use of flue gas has also been reported (Van den Ende et al. 2012).

Microalgal cultures have been used successfully to treat artificial and real wastewater (Ruiz-Marín et al. 2010) and to eliminate nutrients from samples taken at different points in 
a wastewater treatment plant, e.g. after primary settling, or after an activated sludge process, or after an A2O system or oxidation ditch (Yang et al. 2011), as well as in tertiary treatment (Wang et al. 2009). Others, e.g. Li et al (2011), also used centrate for microalgal growth. The satisfactory percentages of nutrients removed in some cases confirm the possibility of combining wastewater treatment with microalgal biomass formation. However, to our knowledge, no previous study of microalgae cultivation for nutrient removal in SAnMBR effluent has been reported. Information obtained from a long term assay on nutrient removal using real wastewater is scarce. In our study, nutrients are removed in an $8 \mathrm{l}$ reactor and under semi-continuous culture conditions. Additionally, the culture is subject to fluctuations of actual wastewater.

Regarding microalgal species, most studies maintain monocultures in order to compare different microorganisms in their ability to eliminate nutrient or generate specific compounds, but the literature is scant on consortia of microorganisms and their performance. This study aims at providing a proof of concept that a mixed polyculture of autochthonous species is able to grow and can be effective in removing nutrients from the studied wastewater, in an approach which considers that strain selection will happen naturally and the culture will thus evolve with changing conditions. To our opinion, this characteristic in the proposed system confers it great robustness and is realistic for industrial application of wastewater treatment. 


\section{MATERIALS AND METHODS}

\subsection{Experimental setup and operation}

2.1.1. Submerged anaerobic membrane bioreactor pilot plant

A flow diagram of the SAnMBR pilot plant is shown in Figure 1. The pilot plant influent was sourced downstream from the pre-treatment units belonging to the Carraixet WWTP (an actual, full-scale wastewater treatment plant in Valencia, Spain) which included coarse screening, degritting and grease removal. The pre-treated wastewater then underwent fine screening (RF) before being pumped into an equalization tank (ET) and then fed into the jacketed anaerobic reactor (AnR, 1300 l) where the temperature was kept above $20^{\circ} \mathrm{C}$.

The anaerobic sludge was circulated between the anaerobic reactor and two $800 \mathrm{l}$

membrane tanks (MT1 and MT2, $600 \mathrm{l}$ working volume). Each membrane tank had a $30 \mathrm{~m}^{2}$ ultrafiltration membrane module (PURON® Koch Membrane Systems, $0.05 \mu$ m pore size). HRT was $13.3 \mathrm{~h}$ and SRT was 30 days for the first 3 weeks of the experiment and then increased to 40 days. Further details of the characteristics and operation of the SAnMBR can be found in a previous study (Giménez et al, 2011). The SAnMBR effluent was collected from the permeate tank (CIP) and taken to the laboratory each day to feed the algae culture in the lab-scale photobioreactor (PBR). 


\subsubsection{Lab-scale photobioreactor}

The PBR consisted of a cylindrical, transparent methacrylate tank (20 cm internal diameter) with a total and working volume of 10 and 8 liters respectively (Figure 2). The PBR was sealed and the algae culture was mixed by recycling the headspace gas at a flow rate of 0.8 $-1.0 \mathrm{l} \mathrm{min}^{-1}$ through four fine bubble diffusers mounted at the bottom. Pure $\mathrm{CO}_{2}(99.9 \%)$ from a pressurized cylinder at 1.5-2 bar pressure was injected into the gas flow in order to maintain a $\mathrm{pH}$ of $7.2 \pm 0.3$ in the PBR. A solenoid valve in synch with the $\mathrm{pH}$ measurements obtained by the data acquisition program opened for 3 seconds every 2 minutes whenever the $\mathrm{pH}$ exceeded the set point value of 7.2. This system enables mixing without using a magnetic stirrer or mechanical agitator, optimizes $\mathrm{CO}_{2}$ consumption and, at the same time, helps control the $\mathrm{pH}$ in the reactor to prevent undesirable phenomena such as phosphate precipitation and ammonia stripping. The seal is however not hermetic. Extreme overpressure is thus avoided and oxygen levels kept close to saturation levels.

Every six hours, one liter of algae culture was taken from the PBR and replaced with the same volume of SAnMBR effluent using two different peristaltic pumps controlled by a personal computer. This corresponds to solids and hydraulic retention times of 2 days. Two arrays of 5 horizontal fluorescent lamps (Sylvania Grolux, 18 W) 30 cm apart continuously illuminated opposite sides of the PBR. Photosynthetically active radiation (PAR) was measured in the bottom, middle and top sections of the illuminated surface of the PBR tank (HOBO ${ }^{\circledR}$ Smart Sensor, s-lia-m003) resulting in values of $159 \pm 39,209 \pm 43$ and $143 \pm$ 
$30 \mu \mathrm{E} \mathrm{m}^{-2} \mathrm{~s}^{-1}$ respectively. During the experiment no temperature control was employed, resulting in temperatures ranging from 28 to $32{ }^{\circ} \mathrm{C}$.

\subsection{Microorganisms}

The microalgae used as inoculum were isolated from the walls of the secondary clarifier in the Carraixet WWTP and kept in 250ml, $1 \mathrm{l}$ and $2 \mathrm{l}$ bottles in the laboratory under semicontinuous feeding conditions with the same effluent used in this study and with continuous illumination varying between 114 and $198 \mu \mathrm{E} \mathrm{m}^{-2} \mathrm{~s}^{-1}$. Microalgae from the chlorococcales order of the Chlorophyceae class were identified as the main group present, together with cyanobacteria.

\subsection{Sampling, monitoring and analysis}

In our study, nutrient removal by algae culture was evaluated by the daily measurement of inorganic nitrogen and phosphate levels in the influent (SAnMBR effluent) and in the soluble fraction taken from the PBR. The soluble fraction of the culture was obtained by membrane filtration with $0.45 \mathrm{~mm}$ pore size glass fiber filters (Millipore). Ammonium $\left(\mathrm{NH}_{4}{ }^{+}-\mathrm{N}\right)$, nitrite $\left(\mathrm{NO}_{2}-\mathrm{N}\right)$, nitrate $\left(\mathrm{NO}_{3}{ }^{-}-\mathrm{N}\right)$ and phosphate $\left(\mathrm{PO}_{4}{ }^{-3}-\mathrm{P}\right)$ levels were determined by applying Standard Methods (APHA 2005) (4500-NH3-G, 4500-NO2-B, 4500-NO3-H, 4500-P-F respectively) in a Smartchem 200 automatic analyzer (Westco Scientific Instruments, Westco). Total nitrogen and total phosphorus in the algae culture were measured in duplicate at least three times a week using standard kits (Merck, 
Darmstadt, Germany, 100613) to measure nitrogen, and the acid peroxodisulphate digestion method to measure phosphorus (APHA 2005). The nitrogen content of the algae biomass was calculated as the difference between total nitrogen and soluble nitrogen. Likewise, the phosphorus content of the particulate fraction was calculated as the difference between total phosphorus and phosphate concentration of the soluble fraction. Total and volatile suspended solids (TSS and VSS) were determined every day as described in Standard Methods (APHA 2005). Samples were taken in duplicate. Chemical oxygen demand was determined from duplicate samples and according to Standard Methods (APHA 2005). To determine the chlorophyll content, $50 \mathrm{ml}$ of culture were filtered using $0.45 \mu \mathrm{m}$ pore size Whatman ${ }^{\circledR}$ cellulose filters which were then frozen at $-20^{\circ} \mathrm{C}$ for 24 hours. Chlorophyll was extracted from the algae biomass that accumulated on the filter using $20 \mathrm{ml}$ of a $90 \%$ acetone-water solution whilst kept in the dark at $4{ }^{\circ} \mathrm{C}$ for at least 24 hours. The extracted chlorophyll and the filters were then centrifuged for 5 minutes at $3000 \mathrm{~g}$ (Eppendorf 5804 centrifuge) and absorbance at 630, 646, 664 and $750 \mathrm{~nm}$ was measured by a UV-VIS spectrophotometer (Merck Spectroquant ${ }^{\circledR}$ Pharo 300). The concentrations of chlorophyll a and $\mathrm{b}$ were calculated by the trichromatic method using the equations of Jeffrey and Humphrey (APHA 2005). Samples were taken in duplicate. The epifluorescence microscopic count method was used to analyze phytoplankton communities. Samples in a 250-ml glass bottle were fixed adding glutaraldehyde until a final concentration of $2 \%$ was attained. They were filtered with $0.2 \mu \mathrm{m}$ membranes (Millipore GTTP) and the filters were washed with distilled water to eliminate the retained salt and then dehydrated with successive 50\%, 80\%, 90\% and 99\% ethanol washes. Each dried filter was placed onto a 
drop of immersion oil in the centre of a slide and two more drops were added on the upper side of the filter. Finally, a cover glass was placed on top of the filter (Fournier 1978). Phytoplankton counts were performed by epifluorescence microscopy with a Leica DM2500, using the $100 \times$-oil immersion objective. A minimum of 300 cells was counted and at least 100 cells of the most abundant species or genera were counted with an error of less than 20\% (Lund et al. 1958). All reported results were obtained from the previous analyses conducted in duplicate.

The physical and chemical parameters of the algae culture such as conductivity, redox potential, temperature, $\mathrm{pH}$ and dissolved oxygen were monitored online in the PBR and logged in a PC using data acquisition software. For conductivity, redox and $\mathrm{pH}$, the signals from the corresponding electrodes were processed by a multiparametric analyzer (CONSORT C832, Belgium), whilst temperature and dissolved oxygen were measured using a Cellox 325 electrode (WTW, Germany) connected to an oximeter (Oxi 320, SET WTW, Germany).

\section{RESULTS AND DISCUSSION}

\subsection{SAnMBR effluent. Nitrogen and phosphorus removal}

The variation in $\mathrm{NH}_{4}{ }^{+}-\mathrm{N}$ and $\mathrm{PO}_{4}^{-3}$-P content during the experiment is depicted in Figs 3 and 4, which also show the levels of these nutrients in the influent to be treated (SAnMBR effluent). Variations in the ammonium and phosphate contents of the PBR influent depend on the operating behavior of the SAnMBR and the properties of its actual wastewater load. 
Neither nutrient addition nor dilution of the effluent took place. The microalgae in the reactor were thus fed exclusively with the SAnMBR effluent, which supplied them with all the dissolved inorganic nutrients they required for growth. Because microalgae need micronutrients other than ammonium and phosphate, e.g. silica, calcium, magnesium, cobalt, potassium, zinc, iron, manganese, sulfur and copper, it can be assumed that these are contained in the SAnMBR effluent, as is usually the case when wastewater is used for algal growth (Christenson and Sims 2011).

Microalgae grow by using inorganic carbon obtained via photosynthetic $\mathrm{CO}_{2}$ fixation. The bicarbonate-carbonate buffer system $\left(\mathrm{CO}_{2}-\mathrm{H}_{2} \mathrm{CO}_{3}-\mathrm{HCO}_{3}{ }^{-}-\mathrm{CO}_{3}{ }^{2-}\right)$ in the culture media can provide $\mathrm{CO}_{2}$ for photosynthesis through the following reactions:

$2 \mathrm{HCO}_{3}{ }^{-} \leftrightarrow \mathrm{CO}_{3}{ }^{2-}+\mathrm{H}_{2} \mathrm{O}+\mathrm{CO}_{2}$

$\mathrm{HCO}_{3}^{-} \leftrightarrow \mathrm{CO}_{2}+\mathrm{OH}^{-}$

$\mathrm{CO}_{3}{ }^{2-}+\mathrm{H}_{2} \mathrm{O} \leftrightarrow \mathrm{CO}_{2}+2 \mathrm{OH}^{-}$

Microalgae, on the other hand, release $\mathrm{CO}_{2}$ through respiration. Dark respiration, however, usually accounts for less than $10 \%$ of total photosynthetic production so its impact is small. Adding carbon dioxide directly to the reactor is, therefore, the best and most convenient way to control $\mathrm{pH}$, while providing a source of inorganic carbon needed for microalgal growth at the same time (Grobbelaar 2004). Different concentrations of carbon dioxide are often added to the reactor by an aeration system (see Ugwu et al. 2008 for review of this topic). The $\mathrm{CO}_{2}$ content of water depends on the thermodynamics and mass transfer phenomena. Inefficient transfer across the gas-liquid interface causes high levels of $\mathrm{CO}_{2}$ in 
the gas phase, resulting in a loss of $\mathrm{CO}_{2}$ if the gas is released into the atmosphere. The system used in this study was designed to optimize carbon dioxide consumption by recirculating the headspace gas while keeping the $\mathrm{pH}$ of the culture at a set value of 7.2. Hence, the composition of the gas phase used to mix the culture and supply carbon depended on the interaction of a) $\mathrm{CO}_{2}$ consumption; b) microalgal respiration; c) the buffer system in the liquid phase, which depends on alkalinity; d) the mass transfer between the gas and liquid phases; and e) the external $\mathrm{CO}_{2}$ added when the $\mathrm{pH}$ of the culture (liquid phase) deviated from 7.2.

A working $\mathrm{pH}$ of 7.2 was deemed suitable for microalgal growth because the optimal $\mathrm{pH}$ levels reported for algal growth are in the 7 - 9 range. On the other hand, one of the main aims of this study was to remove nutrients by assimilation into biomass, avoiding other forms of nutrient removal such as the chemical precipitation of phosphates or ammonia stripping in the gas phase. Both phenomena are enhanced by raising the $\mathrm{pH}$. As reported by Carlsson et al. (1997), the situation for calcium phosphate precipitation is critical when $\log ([\mathrm{Ca}] \cdot[\mathrm{P}])$ approaches 5.4 if the $\mathrm{pH}$ is 7 . In our case, with mean calcium concentrations of $130 \mathrm{mg} \cdot \mathrm{l}^{-1}$, precipitation was avoided when the phosphorus content remained beneath 37 $\mathrm{mg} \cdot \mathrm{l}^{-1}$, which was always achieved. According to De Bashan and De Bashan (2004), struvite (ammonium-magnesium-phosphate) precipitation also takes place when $\mathrm{pH}$ is above 7.5. As regards ammonia stripping, it is known that the ammonium-ammonia equilibrium is highly influenced by $\mathrm{pH}$, such that a $\mathrm{pH}$ higher than 9 shifts the equilibrium enough to facilitate ammonia stripping, whereas with a $\mathrm{pH}$ of $7, \mathrm{NH}_{4}{ }^{+}-\mathrm{N}$ is by far the most dominant form of ammonia nitrogen. The loss of ammonia into the atmosphere became the 
major mechanism explaining nitrogen removal in cultures where $\mathrm{pH}$ was not controlled and therefore it rose as photosynthetic activity increased (Olguín 2003b). Therefore, keeping the $\mathrm{pH}$ at 7.2 ensured that the nitrogen and phosphorus elimination in the proposed system was due mainly to biomass growth. The headspace gas recirculating system optimized $\mathrm{CO}_{2}$ consumption in comparison with the same system without recirculation (data not shown).

Incoming ammonium during the monitored period oscillated between 42.6 and $81.4 \mathrm{NH}_{4}{ }^{+}$-

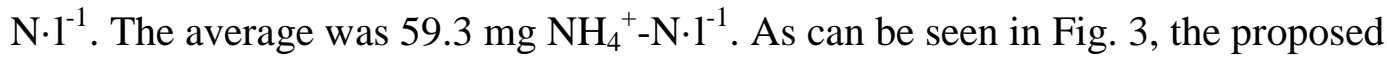
microalgal system for nutrient removal was influenced by these variations. The levels of ammonium in the reactor are highest when levels are highest in the influent, sometimes with 1 or 2 days' delay. Hence, at the end of week 1 the ammonia level in the reactor rose following the tendency of the influent, and remained at around $20 \mathrm{mg} \mathrm{NH}_{4}{ }^{+}-\mathrm{N} \cdot \mathrm{l}^{-1}$ during week 2. It is remarkable that, in periods with no peaks in the incoming concentration, such as weeks 4 and 5, when the ammonia content of the influent remained at around $50 \mathrm{mg}$ $\mathrm{NH}_{4}{ }^{+}-\mathrm{N} \cdot \mathrm{l}^{-1}$, the quality of the effluent was excellent: ammonium levels were very low. Towards the end of the study the $\mathrm{NH}_{4}{ }^{+}$-N concentration rose due to an increase in the SAnMBR effluent. No nitrite or nitrate was detected in the SAnMBR effluent.

Elimination was calculated in terms of total inorganic nitrogen, i.e. not taking into account the amount of $\mathrm{NH}_{4}{ }^{+}-\mathrm{N}$ which was transformed into $\mathrm{NO}_{3}^{-}-\mathrm{N}$ or $\mathrm{NO}_{2}{ }^{-}-\mathrm{N}$ in the reactor. On average, in the given conditions of illumination and temperature, the system studied was able to eliminate daily $38.9 \pm 10 \mathrm{mg}$ of soluble $\mathrm{N}$ in the treated water, which corresponds to a daily removal per reactor volume of $19.5 \pm 5 \mathrm{mg} \cdot \mathrm{l}^{-1} \cdot \mathrm{d}^{-1}$. This is more than or in the same 
range as other studies (e.g. Kim et al. (2010) reported 20-40 $\mathrm{mg}-\mathrm{N} \cdot \mathrm{l}^{-1} \cdot \mathrm{d}^{-1}$ eliminated in a flat panel reactor where the microalga Synechocystis was supplied with $90 \mathrm{mg}-\mathrm{N} \cdot \mathrm{l}^{-1} \cdot \mathrm{d}^{-1}$, Yuan et al. (2011) reported Spirulina platensis growth in an airlift photobioreactor eliminating 10-22 $\mathrm{mg}-\mathrm{N} \cdot \mathrm{l}^{-1} \cdot \mathrm{d}^{-1}$ and Park et al. (2010) reported 5-6 $\mathrm{mg}-\mathrm{N} \cdot \mathrm{l}^{-1} \cdot \mathrm{d}^{-1}$ removal by Scenedesmus from a filtered and autoclaved anaerobic digestion effluent obtained from a piggery farm).

Levels of nitrification (transformation of ammonium into nitrite and nitrate) were very low (on average 13.4\% of incoming ammonium), except at the end of week 3 and week 4 , when non-ammonium nitrogen in the soluble part of the reactor effluent peaked at $22.7 \mathrm{mgN} \cdot \mathrm{l}^{-1}$, i.e. more than $30 \%$ of incoming ammonium. Nitrification is carried out in two steps by nitrifying bacteria, which are also autotrophic microorganisms to be expected in a mixed culture system like the one under study here. Ammonia-oxidizing bacteria (AOB) transform ammonia into nitrite, and nitrite-oxidizing bacteria (NOB) carry out the second step by oxidizing nitrite into nitrate. Although their growth velocities are not always higher than microalgae (Jimenez 2010 reported a maximum growth velocity of $0.88 \mathrm{~d}^{-1}$ and $0.42 \mathrm{~d}^{-1}$, respectively), thin biofilms in the walls of the reactor and other elements could have temporarily been a niche for the development of these microorganisms, preventing them from being washed away and allowing nitrite and nitrate to accumulate in the reactor. The previous accumulation of ammonium in the reactor (during week 2) also provided them, presumably, with the nutrients needed for growth. In week 5, the levels of ammonium in the reactor fell to undetectable values when taken for microalgal growth. This correlates well with the increase in TSS in week 5, after the previous sharp decrease (Fig. 5). In that 
week the microalgae presumably outcompeted the autotrophic bacteria, which were removed at the same time by the manual cleaning of the reactor walls. AOB and NOB, together with nitrite and nitrate, were gradually washed out of the reactor by daily purging. It can be concluded from this section that, when the anaerobic membrane bioreactor was operated steadily with effluent concentrations of around $50 \mathrm{mg} \mathrm{NH}_{4}{ }^{+}-\mathrm{N} \cdot \mathrm{l}^{-1}$, the removal rate of inorganic nitrogen was very satisfactory. In the conditions of light and temperature used in the study and when the incoming ammonia level is higher, it remains in the culture and might be used by autotrophic bacteria that coexist in the reactor with the microalgae.

As regards phosphorus elimination, a satisfactory $97.8 \pm 3.9 \%$ of the incoming phosphate was eliminated, resulting in very high quality treated effluent. This means a daily average elimination of $7.3 \pm 1.6 \mathrm{mg} \mathrm{PO}_{4}^{-3}-\mathrm{P} \cdot \mathrm{l}^{-1}$ in the treated water and a daily removal per reactor volume of $3.7 \pm 0.8 \mathrm{mg} \cdot \mathrm{l}^{-1} \cdot \mathrm{d}^{-1}$. Fig. 4 shows that, despite the incoming phosphate content varying from 5.1 to $10.5 \mathrm{mg} \mathrm{PO}_{4}^{-3}-\mathrm{P} \cdot \mathrm{l}^{-1}$, the soluble part of the microalgal system effluent had a mean phosphate concentration of $0.1 \mathrm{mg} \mathrm{PO}_{4}^{-3}-\mathrm{P} \cdot \mathrm{l}^{-1} \cdot \mathrm{d}^{-1}$ and a maximum of $0.2 \mathrm{mg}$ $\mathrm{PO}_{4}^{-3}-\mathrm{P} \cdot \mathrm{l}^{-1}$. Hence, the phosphate eliminated is very nearly equal to the amount of phosphate found in the SAnMBR effluent. This suggests that phosphate is, in this case, the limiting nutrient. This is also pointed out by the fact that the mass N:P ratio in wastewater ( $8 \pm 1.2$ on average) is higher than the $\mathrm{N}: \mathrm{P}$ ratio the microalgae need for their growth (an average of $5.4 \pm 1.2$ eliminated during this study). However, the fact that the phosphate content is still detectable suggests that the system has another limitation, probably light intensity. It is hypothesized that a higher light intensity would increase biomass production in as much as phosphorus is still available for growth. Previously cited studies in this 
section report similar values for phosphate elimination. In Yuan et al. (2011) between 1.4 and $3 \mathrm{mg} \mathrm{PO}{ }_{4}^{-3}-\mathrm{P} \cdot \mathrm{l}^{-1}$ were eliminated and Kim et al. (2010) report between 2.4 and $3.9 \mathrm{mg}$ $\mathrm{PO}_{4}^{-3}-\mathrm{P} \cdot \mathrm{l}^{-1}$

Soluble COD content in the photobioreactor was monitored after week 3 and displayed an average value of $51 \mathrm{mgCOD} \cdot \mathrm{l}^{-1}$. Previous experiments (unpublished data) show that this COD corresponds mainly to non-biodegradable soluble organic matter which is present in the SAnMBR effluent.

\subsection{Biomass production and biomass $\mathbf{N}$ and $\mathbf{P}$ content}

The evolution of algal biomass, measured using TSS (mg $\mathrm{l}^{-1}$ ), and its chlorophyll content $\left(\mathrm{mg} \cdot \mathrm{gTSS}^{-1}\right.$ ) is shown in Fig. 5. The maximum biomass level was $595 \mathrm{mg} \cdot \mathrm{l}^{-1}$, and the

average over the entire period, $467 \pm 65 \mathrm{mg} \cdot \mathrm{l}^{-1}$. Mean chlorophyll content ranged from 20.5 to $48.2 \mathrm{mg} \cdot \mathrm{g}^{-1}$ in the biomass $(2-4.8 \% \mathrm{dw}$ ), which is in keeping with other studies (Cheirsilp and Torpee 2012). Self shadowing increases with higher TSS in the culture and the chlorophyll content of the microalgae increases in order to increase light harvesting. Because of the high nitrogen content of chlorophyll, there is a relationship between soluble nitrogen elimination (shown in fig. 6, corrected for nitrite and nitrate) and the chlorophyll content of the culture (expressed in mg chl a+b per liter of culture). It is therefore expected that a higher biomass concentration with limited available light would increase the chlorophyll content of the culture and thus improve the nitrogen elimination. The increase in the consumed $\mathrm{N}: \mathrm{P}$ ratio would be of interest in the case of this specific SAnMBR effluent to be treated and future research should aim to increase the biomass concentration. 
The biomass production rate (BPR) and the specific growth rate ( $\mu$ ) were calculated by equations 4 and 5 below, respectively:

$$
\begin{aligned}
& B P R=\frac{X \cdot Q}{V}\left(\mathrm{mg} \cdot \mathrm{l}^{-1} \cdot \mathrm{d}^{-1}\right) \\
& \mu=\frac{\ln X_{2}-\ln x_{1}}{t_{2}-t_{1}}\left(\mathrm{~d}^{-1}\right)
\end{aligned}
$$

where $X$ is the biomass concentration $\left(\mathrm{mg} \cdot \mathrm{l}^{-1}\right), Q$ is the flow rate in semi-continuous operation, $V$ is the reactor volume and $t$ is time. Results showed an average biomass production of $234 \pm 32 \mathrm{mg} \cdot \mathrm{l}^{-1} \cdot \mathrm{d}^{-1}$ and an average daily specific growth rate of $0.66 \pm 0.15$ $\mathrm{d}^{-1}$, which is similar to those previously reported (Kim et al. 2010, Ras et al. 2011, Ketheesan and Nirmalakhandan 2012).

Microalgae cell counts, together with the distribution of Chlorophyceae, Diatoms and Cyanobacteria, are shown in Table 1. The mixed culture originally rich in cyanobacteria developed during cultivation time into a polyculture in which Chlorophyceae were the dominant class. The Diatoms content was low throughout the studied period.

As reported elsewhere, different species of microalgae have diverse nutrient affinities and are influenced differently by environmental conditions. The advantage of maintaining a system containing different microalgal species is that a polyculture is able to adjust to varying conditions such as nutrient concentration or temperature. Moreover, although $\mathrm{pH}$ and light intensity were kept stable in this experiment, process control is more difficult or 
more expensive on a larger scale or in outdoor cultures. Variable conditions in such cases would demonstrate the robustness of polycultures. Further research should aim at understanding species distribution and evolution for better operation and control. The P and N contents of the biomass were calculated as a \% of dry weight as follows:

$\% N=\frac{\text { particulate } N\left(\mathrm{mg}_{\mathrm{g}} \mathrm{l}^{-1}\right)}{\operatorname{TSS}\left(\mathrm{mg} \cdot \mathrm{l}^{-1}\right)}$
$\% P=\frac{\text { particulate } P\left(\mathrm{mg} \cdot \mathrm{l}^{-1}\right)}{\operatorname{TSS}\left(\mathrm{mg}_{\mathrm{g}} \cdot \mathrm{l}^{-1}\right)}$

The average biomass compositions thus obtained were $7.72 \pm 1.51 \% \mathrm{~N}$ and $1.44 \pm 0.16 \% \mathrm{P}$, which revealed the average mass $\mathrm{N}: \mathrm{P}$ ratio in the microalgae to be 5.36 , which tallies well with the eliminated $\mathrm{N}$ :P ratio presented in section 3.1, i.e. $5.4 \pm 1.2$. With this biomass average composition, the nitrogen and phosphorus assimilated into the biomass during the studied period account for $92 \%$ and $91 \%$ of the eliminated nitrogen and phosphorus, respectively. Also reported in section 3.1, the mass N:P ratio in the influent ranged from 5.3 to 10.3, being 8 on average . Hence the SAnMBR effluent has a nitrogen surplus: it is phosphorus deficient and therefore eliminates this nutrient to a greater extent.

\subsection{Biomass separation and future perspectives}

The biomass generated enables the nutrients that have been removed from the wastewater to be recycled. Another separation step is needed to extract the microalgae from the culture medium and provide an effluent free of solids. Studies of membrane systems for microalgal biomass separation have been conducted (Rossignol et al. 1999, Zhang et al. 2010), but not very extensively. Further research will focus on microalgal biomass separation with 
membrane systems, assuming that separating solids retention time from hydraulic retention time will enable the proposed system to be optimized. The algal biomass thus obtained and separated from the culture could then be recycled at the anaerobic stage and used to increase the production of biogas. At the same time, it is of great importance to scale up the system to pilot plant scale and study it under outdoor conditions in order to develop a suitable technology for real scale urban wastewater treatment using the proposed mixed microalgal culture.

\section{CONCLUSIONS}

This study determines that it is feasible to use a mixed microalgal culture system for nutrient removal from AnMBR effluents, which could be a first step into spreading their use for domestic wastewater treatment. High nutrient removal rates were maintained whilst operating semi-continuously for 42 days, resulting in a microalgal treatment effluent whose water quality was very good. The combined system proposed, i.e. anaerobic treatment followed by microalgal polyculture, thereby eliminates organic matter from real urban wastewater whilst generating biogas, and the remaining ammonium and phosphate are recovered by transformation into microalgal biomass, achieving excellent water quality. 


\section{ACKNOWLEDGEMENTS}

This research project has been supported by the Spanish Research Foundation (CICYT, projects CTM2011-28595-C02-01 and CTM2011-28595-C02-02), whose support is gratefully acknowledged.

\section{REFERENCES}

[1] APHA, A., WEF, 2005. Standard Methods for the Examination of Waters and Wastewaters. $21^{\text {st }}$ ed. Washington DC.

[2] Brenan, M., Owende, P., 2010. Biofuels from microalgae - A review of technologies for production, processing, and extraction of biofuels and co-products. Renew. Sustain. Energ. Rev. 14, 557-577.

[3] Carlsson, H., Aspegren, H., Lee, N., Hilmer, A., 1997. Calcium phosphate precipitation in biological phosphorus removal systems. Water Research 31, 1047 1055.

[4] Cheirslip, B., Torpee, S., 2012. Enhanced growth and lipid production of microalgae under mixotrophic culture condition: Effect of light intensity, glucose concentration and fed-batch cultivation. Bioresour. Technol. 110, 510-516.

[5] Chisti, Y., 2008. Biodiesel from microalgae beats bioethanol. Trends Biotechnol. 26, 126-131.

[6] Christenson, L., Sims, R., 2011. Production and harvesting of microalgae for wastewater treatment, biofuels, and bioproducts. Biotechnol. Adv. 29, 686-702. 
[7] De Bashan, L., Bashan, Y., 2004. Recent advances in removing phosphorus from wastewater and its future use as fertilizer (1997-2003). Water Res. 38, 4222-4246.

[8] Fournier, R., 1978. Membrane filtering. In: Sournia, A. (Ed.), Phytoplankton Manual. Monographs on oceanographic Methodology, Unesco, pp. 197-201.

[9] Giménez, J.B., Robles, A., Carretero, L., Durán, F., Ruano, M.V., Gatti, M.N., Ribes, J., Ferrer, J., Seco, A., 2011. Experimental study of the anaerobic urban wastewater treatment in a submerged hollow-fibre membrane bioreactor at pilot scale. Bioresour. Technol. 102, 8799-8806.

[10] Grobbelaar, J.U., 2004. Algal nutrition. In: Richmond, A. (Ed.), Handbook of microalgal culture: biotechnology and applied phycology, Blackwell Publishing, Oxford, pp. 97-115.

[11] Ho, J., Sung, S., 2010. Methanogenic activities in anaerobic membrane bioreactors (AnMBR) treating synthetic municipal wastewater. Bioresour. Technol. 101, 2191-2196.

[12] Jimenez Douglas, E., 2010. Mathematical modeling of the 2 step nitrification process. Development of calibration methodologies for a SHARON reactor and an Activated Sludge Process. (Modelación matemática del proceso de nitrificación en dos etapas. Desarrollo de metodologías de calibración del modelo para un reactor SHARON y un proceso de fangos activados). Universidad Politécnica de Valencia, Valencia, Spain. 
cultivation in a pilot-scale airlift-driven raceway reactor. Bioresour. Technol. 108, 196-202.

[14] Kim, H.W., Vannela, R., Zhou, C., Harto, C., Rittmann, B. E., 2010.

Photoautotrophic nutrient utilization and limitation during semi-continuous growth of Synechocystis sp. PCC6803. Biotechnol. Bioeng. 106, 553-563.

[15] Li, Y., Chen, Y., Chen, P., Min, M., Zhou, W., Martinez, B., Zhu, J., Ruan, R., 2011. Characterization of a microalga Chlorella sp. well adapted to highly concentrated municipal wastewater for nutrient removal and biodiesel production. Bioresour. Technol. 102, 5138-5144.

[16] Oswald, W.J., Gotaas, H.B., 1957. Photosynthesis in sewage treatment. Trans. Am. Soc. Civ. Eng. 122, 73-105.

[17] Olguín, E.J., 2003a. Phycoremediation: key issues for cost-effective nutrient removal processes. Biotechnol. Adv. 22, 81-91.

[18] Olguín, E., Galicia, S., Mercado, G., Pérez, T., 2003b. Annual productivity of Spirulina (Arthrospira) and nutrient removal in a pig wastewater recycling process under tropical conditions. J. Appl. Phycol. 15, 249-25.

[19] Park, J., Jin, H., Lim, B-R., Park, K-Y., Lee, K., 2010. Ammonia removal from anaerobic digestion effluent of livestock waste using green alga Scenedesmus sp. Bioresour. Technol. 101, 8649-8657.

[20] Park, J.B.K., Craggs, R.J., Shilton, A.N., 2011. Wastewater treatment high rate algal ponds for biofuel production. Bioresour. Technol. 102, 35-42. 
[21] Pittman, J.K., Dean, A. P., Osundeko, O., 2011. The potential of sustainable algal biofuel production using wastewater resources. Bioresour. Technol. 102, 1725.

[22] Pulz, O., Gross, W., 2004. Valuable products from biotechnology of microalgae. Appl. Microbiol. Biotechnol. 65, 635-648.

[23] Ras, M., Lardon, L., Sialve, B., Bernet, N., Steyer, J-P., 2011. Experimental study on a coupled process of production and anaerobic digestion of Chlorella vulgaris. Bioresour. Technol. 102, 200-206.

[24] Rawat, I., Ranjith Kumar, R., Mutanda, T., Bux, F., 2010. Dual role of microalgae: Phycoremediation of domestic wastewater and biomass production for sustainable biofuels production. Appl. Energ. 88, 3411-3424.

[25] Ruiz-Marín, A., Mendoza-Espinosa, L.G., Stephenson, T., 2010. Growth and nutrient removal in free and immobilized green algae in batch and semicontinuous cultures treating real wastewater. Bioresour. Technol. 101, 58-64.

[26] Rossignol, N., Vandanjon, L., Jaouen, P., Quéméneur, F., 1999. Membrane technology for the continuous separation microalgae /culture medium: compared performances of cross-flow microfiltration and ultrafiltration. Aquacult. Eng. 20, 191-208.

[27] Schenk, P., Thomas-Hall, S., Stephens, E., Marx, U., Mussgnug, J., Posten, C., Kruse, O., Hankamer, B., 2008. Second generation biofuels: high-efficiency microalgae for biodiesel production. Bioenergy Res. 1, 20-43. 
Perspectives on anaerobic membrane bioreactor treatment of domestic wastewater: A critical review. Bioresour. Technol. http://dx.doi.org/10.1016/j.biortech.2012.04.055

[29] Stuckey, D.C, 2012. Recent developments in anaerobic membrane reactors. Bioresour. Technol. http://dx.doi.org/10.1016/j.biortech.2012.05.138

[30] Ugwu, C.U., Aoyagi, H., Uchiyama, H., 2008. Photobioreactors for mass cultivation of algae. Bioresource Technology 99, 4021-4028.

[31] Van den Ende, S., Vervaeren, H., Boon, N., 2012. Flue gas compounds and microalgae: (Bio-)chemical interactions leading to biotechnological opportunities. Biotechnol. Adv. http://dx.doi.org/10.1016/j.biotechadv.2012.02.015 Wang, L., Min, M., Li, Y., Chen, P., Chen, Y., Liu, Y., Wang, Y., Ruan, R., 2010. Cultivation of green algae Chlorella sp. in different wastewaters from municipal wastewater treatment plant. Appl. Biochem. Biotechnol. 162, 1174-1186.

[33] Yang, J., Li, X., Hu, H., Zhang, X., Yu, Y., Chen, Y., 2011. Growth and lipid accumulation properties of a freshwater microalga, Chlorella ellipsoidea YJ1, in domestic secondary effluents. Appl. Energ. 88, 3295-3299.

[34] Yuan, X., Kumar, A., Sahu, A.K., Ergas, S.J., 2011. Impact of ammonia concentration on Spirulina platensis growth in an airlift photobioreactor. Bioresour. Technol. 102, 3234-3239. 
[35] Zhang, X., Hu, Q., Sommerfeld, M., Puruhito, E., Chen, Y., 2010.

Harvesting algal biomass for biofuels using ultrafiltration membranes. Bioresour.

Technol. 101, 5297-5304. 


\section{FIGURE CAPTIONS}

Figure 1. Flow diagram of the SAnMBR pilot plant. Nomenclature: RF: rotofilter; ET: equalisation tank; AnR: anaerobic reactor; MT: membrane tanks; DV: degasification vessel; CIP: clean-in-place; P: pump; and B: blower.

Figure 2. Lab-scale cylindrical photobioreactor. $\mathrm{CO}_{2}$ is automatically injected into the headspace gas recirculation system for $\mathrm{pH}$ control

Figure 3. Soluble nitrogen evolution in the influent (actual SAnMBR effluent) and in the 81 photobioreactor

Figure 4. Soluble phosphorus evolution in the influent (actual SAnMBR effluent) and in the 81 photobioreactor

Figure 5. TSS $\left(\mathrm{mg} \cdot \mathrm{l}^{-1}\right)$ in the 81 photobioreactor and biomass chl a+b content $\left(\mathrm{mg} \cdot \mathrm{g}^{-1}\right)$

Figure 6. Relation between eliminated nitrogen and reactor chlorophyll content (in mg chl $\left.\mathrm{a}+\mathrm{b} \cdot \mathrm{l}^{-1}\right)$

Table 1. Cell counts and microalgae classification during the experiment 
Figure 1

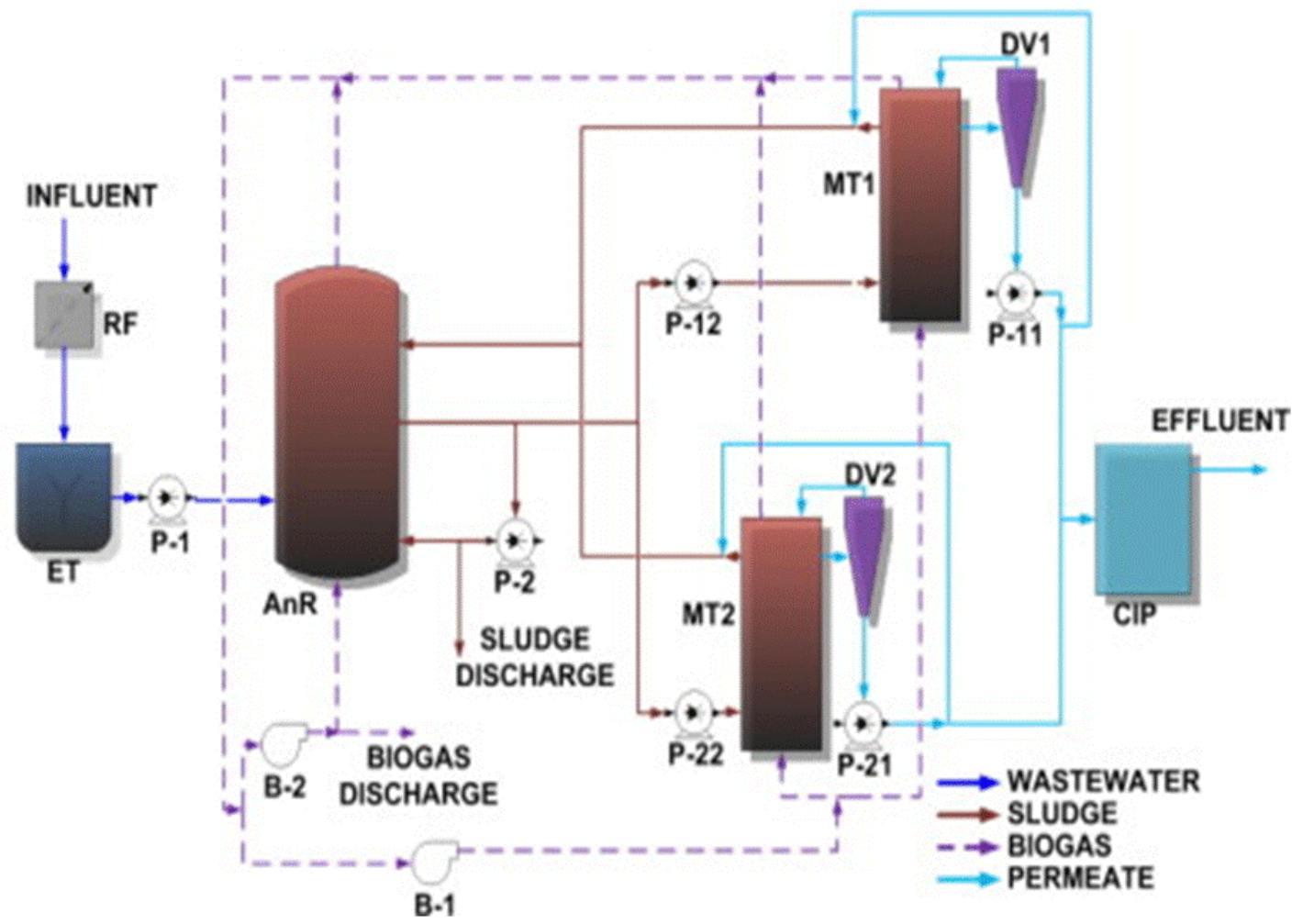


Figure 2

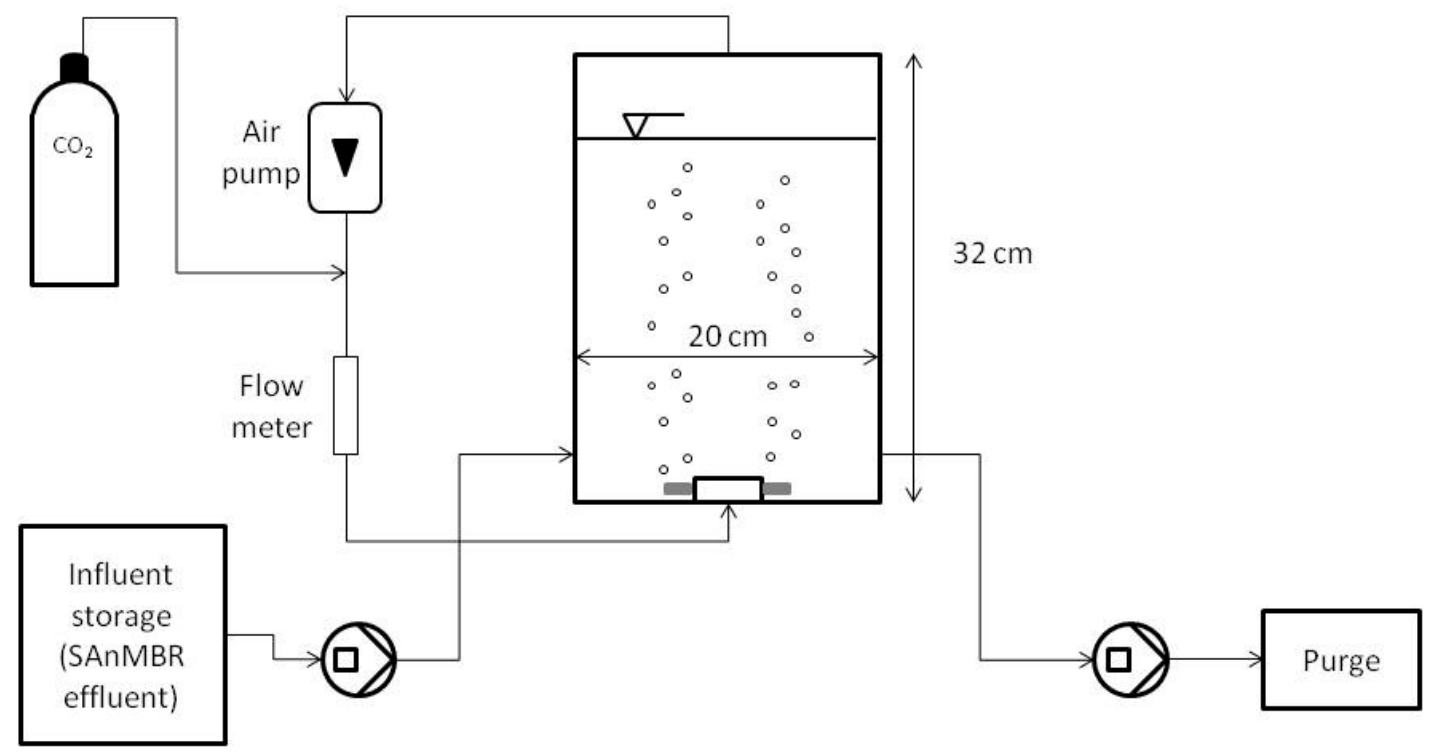


Figure 3

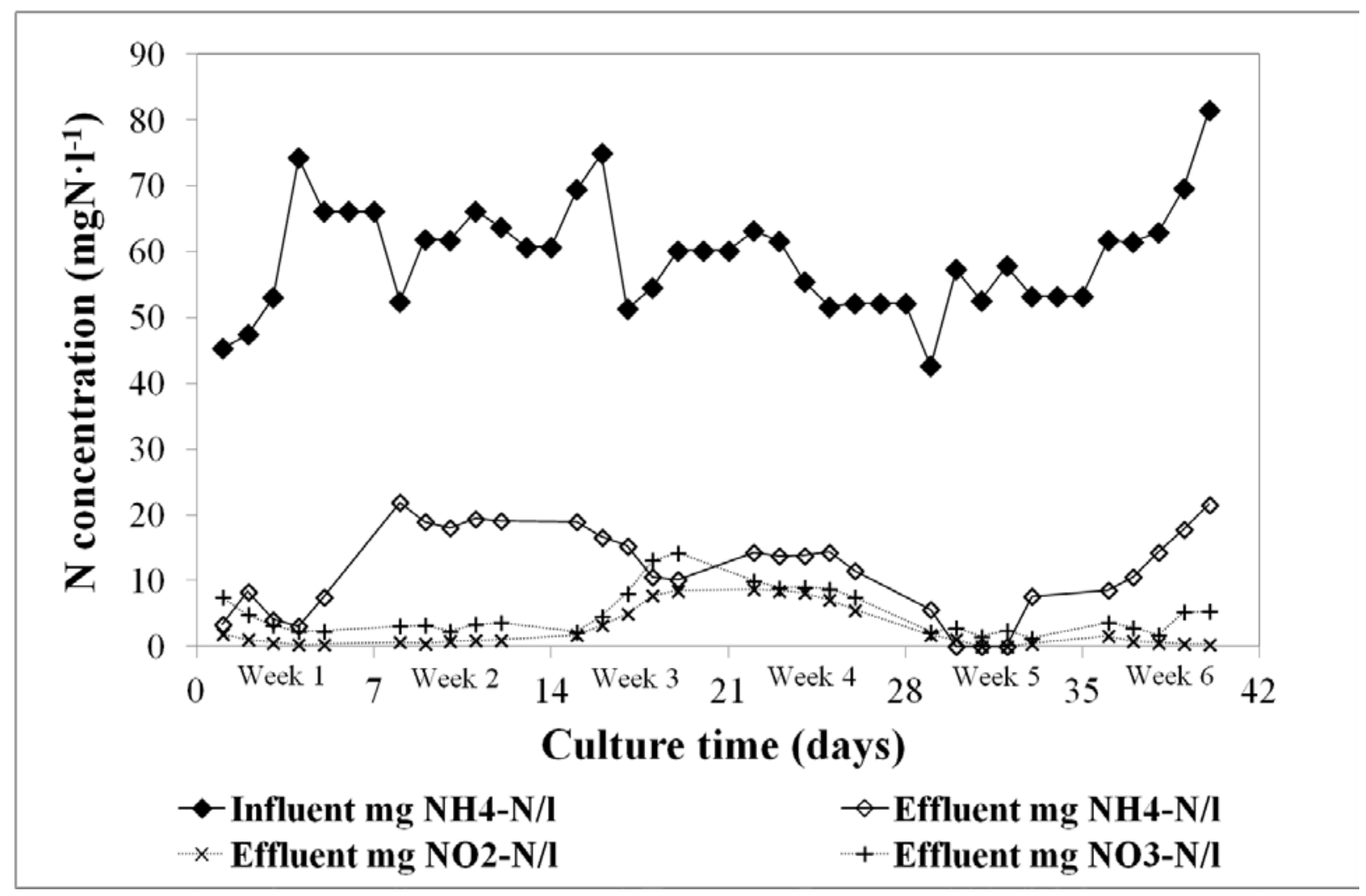


Figure 4

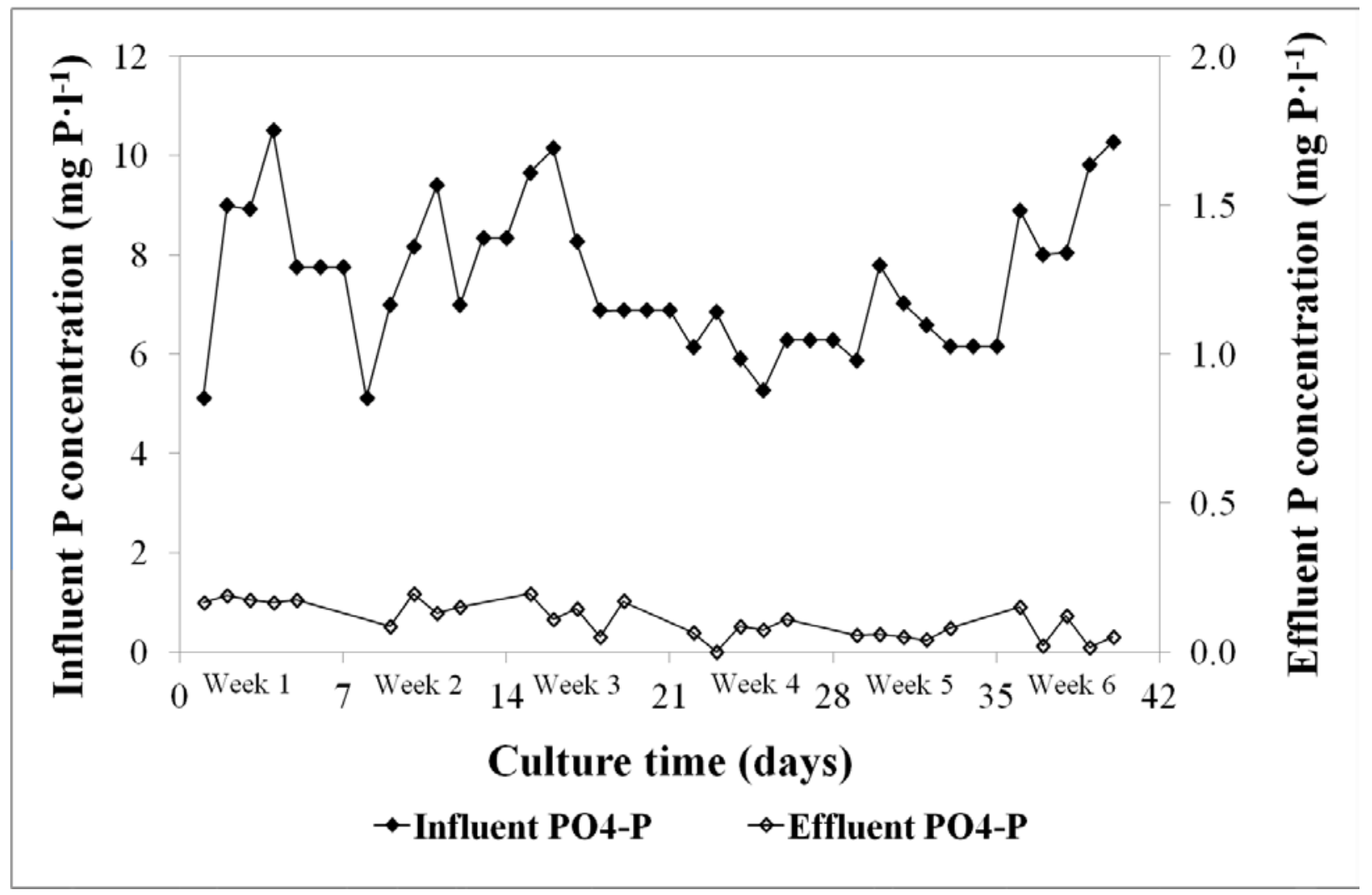


Figure 5

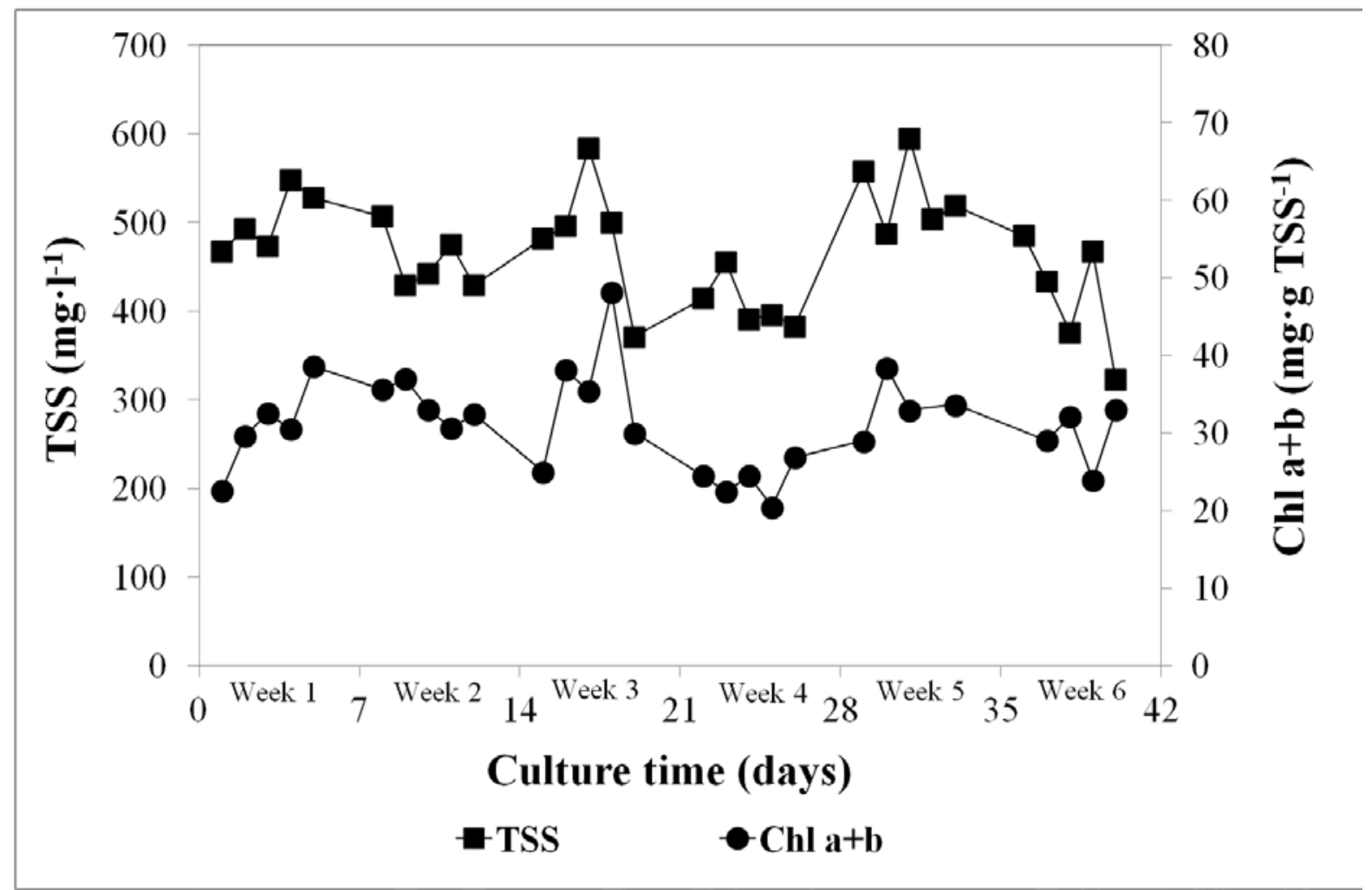


Figure 6

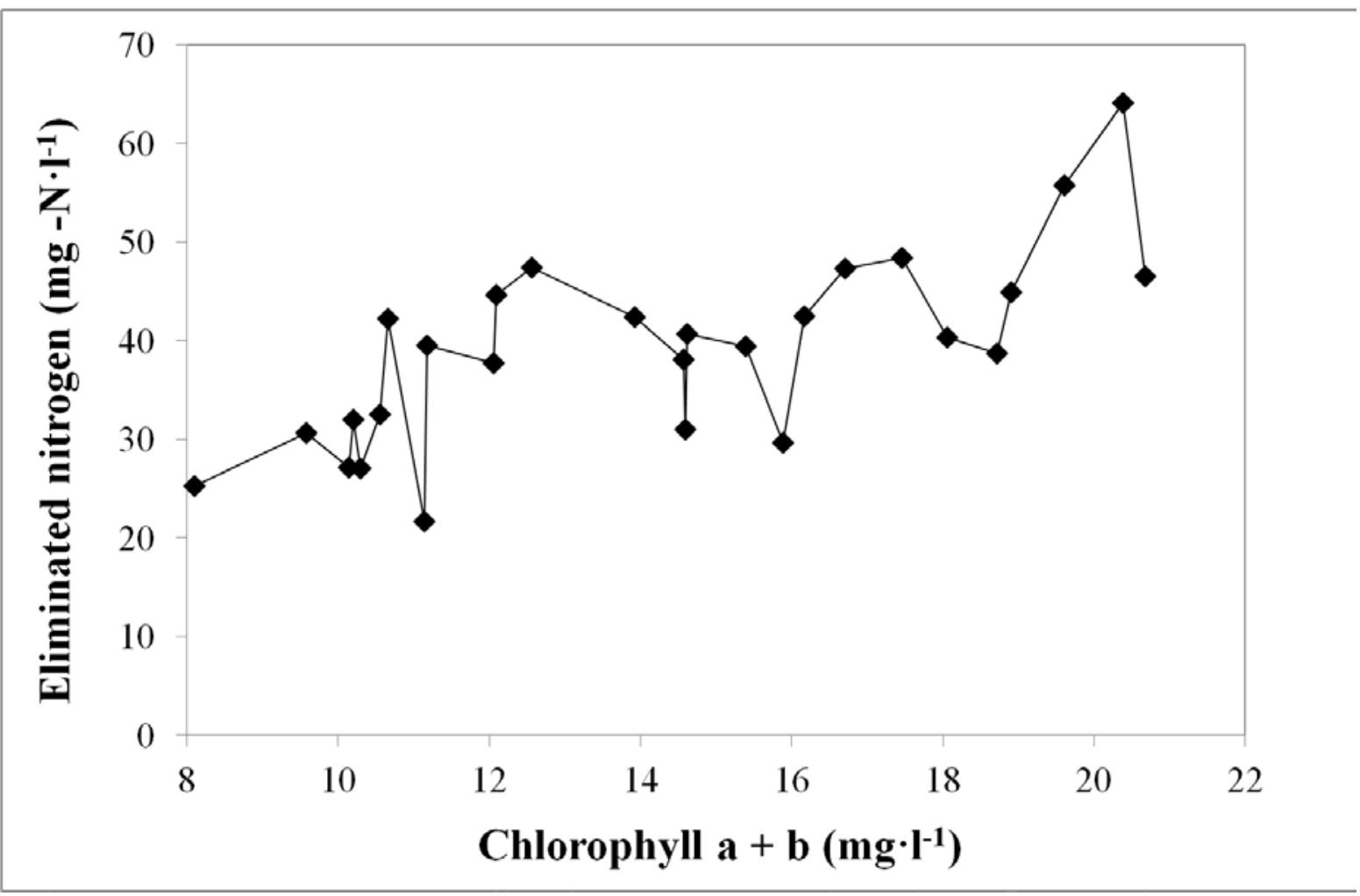


Table 1

\begin{tabular}{|c|c|c|c|c|c|c|c|}
\hline \multirow[b]{2}{*}{$\begin{array}{l}\text { Culture } \\
\text { time (d) }\end{array}$} & \multirow[b]{2}{*}{$\begin{array}{c}\text { Total cell } \\
\text { count }\end{array}$} & \multirow[b]{2}{*}{$\begin{array}{c}\text { Cell } \\
\text { count }\end{array}$} & \multicolumn{2}{|c|}{ Chlorophyceae } & Diatoms & \multicolumn{2}{|c|}{ Cyanobacteria } \\
\hline & & & $\%$ & $\begin{array}{c}\text { Cell } \\
\text { count }\end{array}$ & $\%$ & $\begin{array}{c}\text { Cell } \\
\text { count }\end{array}$ & $\%$ \\
\hline 3 & $4.40 \cdot 10^{9}$ & $1.48 \cdot 10^{8}$ & $3.35 \%$ & - & - & $4.26 \cdot 10^{9}$ & $96.65 \%$ \\
\hline 10 & $6.72 \cdot 10^{9}$ & $4.33 \cdot 10^{9}$ & $64.36 \%$ & $1.72 \cdot 10^{7}$ & $0.26 \%$ & $2.38 \cdot 10^{9}$ & $35.38 \%$ \\
\hline 24 & $3.98 \cdot 10^{9}$ & $2.62 \cdot 10^{9}$ & $65.71 \%$ & $1.24 \cdot 10^{8}$ & $3.12 \%$ & $1.24 \cdot 10^{9}$ & $31.18 \%$ \\
\hline 40 & $2.56 \cdot 10^{9}$ & $1.85 \cdot 10^{9}$ & $72.13 \%$ & $3.82 \cdot 10^{6}$ & $0.15 \%$ & $7.11 \cdot 10^{8}$ & $27.72 \%$ \\
\hline
\end{tabular}

